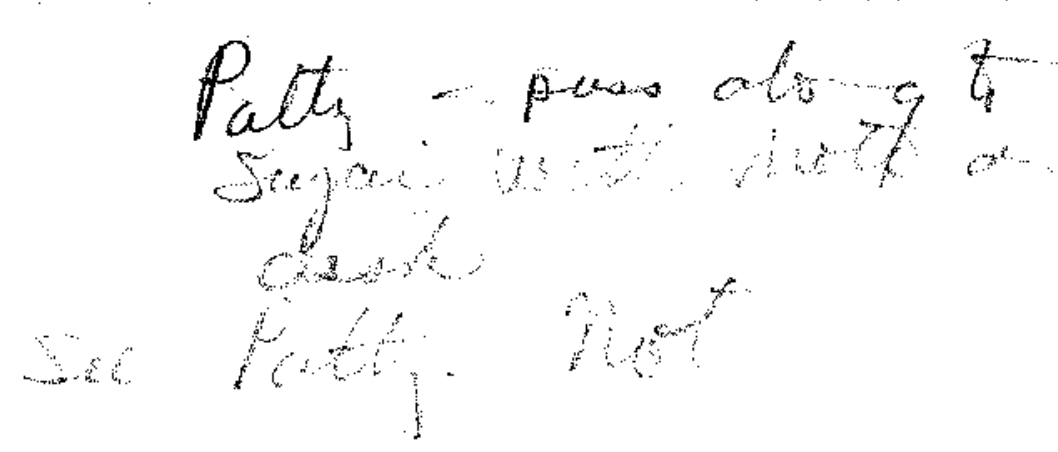

Draft Version: 08/04/00

\title{
Collective Action, Property Rights and Decentralization in Resource Use in India and Nepal
}

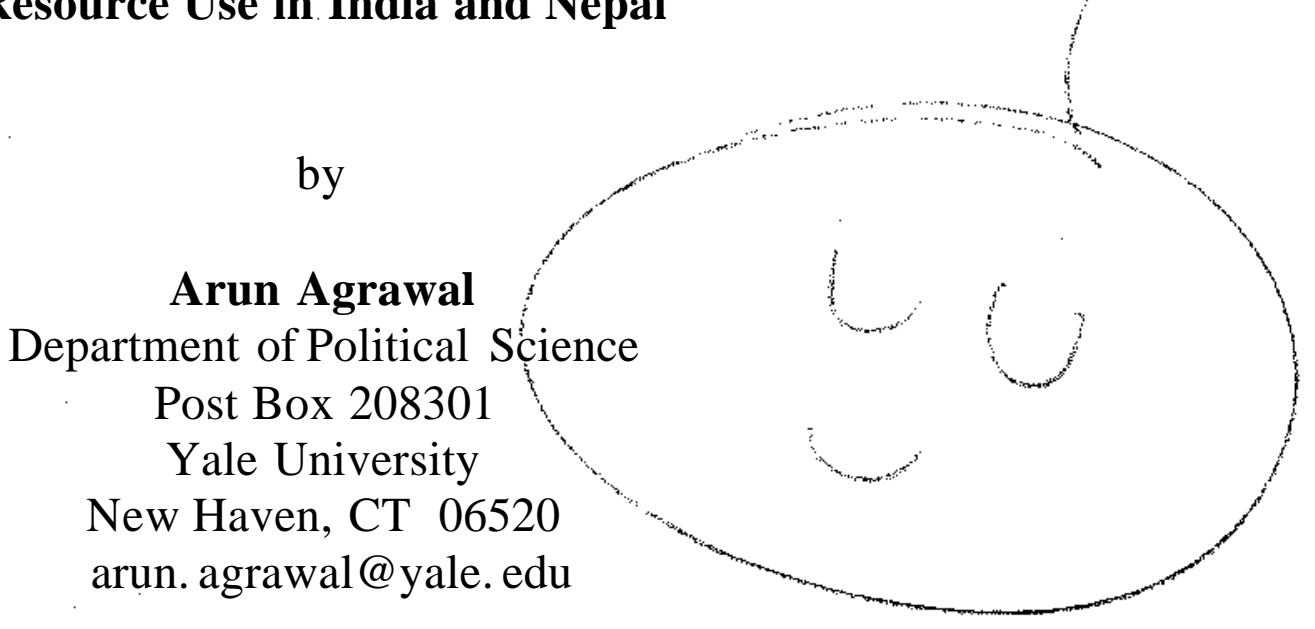

and

\section{Elinor Ostrom}

Workshop in Political Theory and Policy Analysis

513 North Park

Indiana University

Bloomington, IN 47408-3895

ostrom@indiana.edu

Paper prepared for presentation at the Annual Meeting of the American Political Science Association,

September 2000, Washington DC. 


\section{Collective Action, Property Rights, and Decentralization in Resource Use in India and Nepal}

Decentralization has emerged as a major strategy to achieve goals of development, service provision, and environmental conservation in many nation states. It has begun to orient the behavior of political leaders, members of bureaucracies, international donors, and in many places, of local residents and leaders. According to a recent report from the World Bank, "out of 75 developing and transitional countries with populations greater than 5 million, all but 12 claim to be embarked on some form of transfer of political power to local units of governments" Dillinger 1994: 8). Since decentralization has periodically been an important objective of state policy, ${ }^{1}$ a large literature has tried to throw light on its antecedents and results.

This paper focuses on decentralization of central state control over natural resources, especially forests. The subject is important for at least three reasons. The lives of millions of households are affected by how governments manage forests and their willingness to admit local claims. Two, the factors that lead to durable decentralization of forests may be relevant in other arenas in which attempts at decentralization are being analyzed. And finally, decentralized decision making can be seen as an inherently important concern of democratic life.

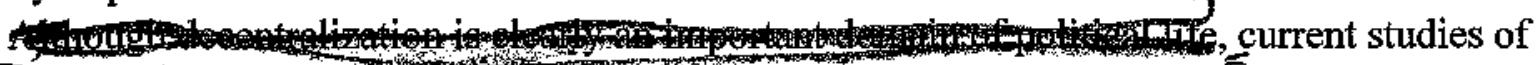
decentralization, especially where natural resources are concerned, suffer from two significant lacunae They are relatively inattentive to political questions of why states attempt decentralization/It is true that many writings arguef for the superiority of decentralization to centralized solutions on grounds of efficiency/ equity/or sustainability. But such advocacy can only show why decentralization should be pursued, not why political actors choose to pursue it $/ \mathrm{A}$ second gap relates to questions of property rights. Inattention to the nature of property rights that central states devolve to Tower level authorities means that we do not well understand which forms of authority at local levels are necessary for successful decentralization. Often we cannot even be sure if claims that a government has decentralized authority can be taken at their face value.

In this paper, we undertake an initial analysis of the political aspects of decentralization by
examining local politics. Our focus on local actors helps pinpoint their influence on origins and implementation of decentralization programs related to forest resources. To address the second gap in writings on decentralization, we draw from the literature on property rights. We propose that the extent of decentralization can be assessed by examining the rights and capacities in specific action domains that are transferred to actors at lower levels of political organization. This approach leads to a more precise framework to understand the nature of decentralization.

Four contrasting studies of decentralization of forests in South Asia help us pursue answers to the analytical questions this paper addresses: What role do local populations play in ensuring that these types of property rights are actually devolved? And what types of property rights must be devolved to

${ }^{1}$ The global pursuit of decentralization, even if it appears novel, has had several precursors. Beginning from 1917, four waves of decentralization can be discerned in Francophone West Africa (Ribot 1999). In South Asia, at least three waves are visible since the mid-1800s (Agrawal and Ribot 1999: 495). 
local populations for effective decentralization. The four comparative case studies we use are a) the Forest Councils of Kumaon in India; b) Joint Forest Management in India; c) Community Forestry in Nepal; and d) the Parks and People Program in Nepal. The four cases exemplify different origins of pressures for decentralization of forest governance, different property rights that central governments devolved, and different outcomes of decentralization. They therefore constitute four instances for a comparative examination of causal relationships in decentralization processes.

\section{The Politics of Decentralization}

At its most basic, decentralization aims to achieve one of the central aspirations of just political governance--democratization, or the desire that humans should have a say in their own affairs. But decentralization is also synonymous with redistribution of power, resources, and administrative capacities through different territorial units of a government and across local groups. Therefore, the most important element in understanding decentralization and whether it is likely to occur is attention to the politics that surrounds it.

Decentralization can be seen as a strategy of governance, prompted by external or domestic pressures to facilitate transfers of power closer to those who are most affected by the exercise of power (Evans 1992; Mawhood 1983; 1987; and Wunsch and Olowu 1990). This understanding of decentralization implies that in analyzing any such initiative, it is critical the major actors involved to identify the interests Among the most important actors who affect decentralization are factions within centrâl governments, local organizations NGOs, and international donors. These

categories are large aggregations and in different contexts, their decentralization-related interests are often likely to remain unpredictable without close attention to the context. This is especially true for central actors. Consequently, the relationship between central and local governments can be ambiguous where local governments can be viewed by their superiors either as trusted agents or as contestants for powers (Goodwin et al., 1996; Rhodes, 1988). To understand why a central government might initiate decentralization reforms and give up control over collective and operational choices in some instances and not others, it is necessary to examine the political relationship between different local and central actors, the role of international donors and NGOs, and how decentralization reforms serve the interests of these actors. An additional question that requires attention is when do decentralization reforms continue, after being initiated.

The question of why a central government would pursue decentralization and voluntarily give up some of its powers to less powerful local governments may seem paradoxical. But instead of viewing a central government as a unified set of actors, it is more useful to see it as a set of actors who have different and perhaps conflicting objectives as they pursue a diversity of goals including gaining power. Once the center itself is seen as divided, decentralization can be hypothesized to take place when actors at the central level compete for power among themselves and find in the process of decentralization a mechanism to enhance their access to resources and power in comparison to other political actors at the central level.

Such a conceptualization of decentralization allows the beginnings of a more political answer to, "why should powerful political actors at the level of a central authority willingly devolve authority, power, and resources to less powerful political actors at regional or local levels?" We should expect to see decentralization of power and decision-making responsibilities when some central political actor(s) or a coalition of such actors find(s) that decentralization makes it possible to reduce costs, deflect 
blame, or extend state reach farther into social processes. It is when such calculations are present that we might see powerful support for decentralization. Without such support, it is unlikely that meaningful decentralization will take place. Even if decentralization programs are initiated, they are likely to suffer setbacks and retreat. Local actors have an important role to play in the initiation of decentralization reforms, but by themselves they are likely not to have the requisite resources or capacities to push for decentralization. A clearer understanding of the origins of decentralization, therefore, requires attention to the major actors involved and their interests.

If the initiation of decentralization policies is a highly political affair, so is their maintenance. Once again, the support of some central state political actor may be essential, but for long-term success it is as important to examine how local level politics articulates with decentralization reforms. Ultimately, because local political actors are less powerful than international donors or central government actors, their interests are likely ignored in decentralization unless they can form effective lobbying groups through networking or organization. The trick for advocates of decentralization therefore, is to align the private interests of powerful decision-makers who are responsible for making collective choices about forestry policies with the attempt to facilitate organization of local actors who can create additional pressures in their favor. ${ }^{2}$

\section{Property Rights and Decentralization}

The multidimensionality of decentralization is reflected in the many terms that refer to it, among them, deconcentration, delegation, devolution, deregulation, privatization, and denationalization. ${ }^{3}$ In the context of the management of natural resources, decentralization can be defined as any act by which a central government cedes rights of decision-making over resources to actors and institutions at lower levels in a politico-administrative and territorial hierarchy. ${ }^{4}$ Usually, the means through which new actors and institutions come to gain new powers of decisionmaking are different combinations of property rights. ${ }^{5}$ Property rights themselves can be defined as relationships among actors with respect to things (Bromley 1992) such as natural resources. Property rights are always contestable, and the degree to which they are actually contested contributes to attenuation of the capacity of the holder to exercise them effectively.

${ }^{2}$ This paper brackets the question of when local groups will self-organize. For a careful analysis of this question see Ostrom $(1990,1999)$.

${ }^{3}$ For definitions of these terms and their relationship to decentralization, see Rondinelli et al. 1989, Ostrom et al. 1993, Maniates 1990, Dahal 1996, Rondinelli and Nellis 1985, Dahal 1996, and Smoke 1993. A large literature elaborates the meanings of decentralization, and we refer only to the directly relevant arguments.

${ }^{4}$ Philip Mawhood, Local Government in the Third World (Chichester: John Wiley, 1983); Brian C. Smith, Decentralization: The Territorial Dimension of the State (London: George Allen, 1985).

${ }^{5}$ As Commons (1968) has observed, a property right is an enforceable authority to undertake particular actions in a specific domain. 
Typically, successful decentralization of resource management results in the creation of new common resources as central governments shift control through delegation of property rights to new actors who can make decisions about the disposition of these resources. The creation of new commons is an important development in natural resource policies worldwide. ${ }^{6}$ As government formulate new rules, they allow district and other lower level actors greater leeway in deciding the fate of locally situated resources. When decentralization is relatively far reaching, as for forests in India through the Joint Forest Management Program, or in Nepal's Community Forestry, even local residents in village communities and their representatives can come to gain new powers of decisionmaking and new property rights over local forest resources. Since decentralization of the type governments are currently undertaking in developing countries is ostensibly designed to create and manage common resources better, the large literature on common property theory is especially useful to analyze the extent to which decentralization programs are successful.

Different types of property rights over resources, whether held juridically, or exercised authoritatively, can create varying consequences for use and management. Schlager and Ostrom (1992) identify five property rights that are most relevant for the use of common-pool resources: access, withdrawal, management, exclusion, and alienation. These are defined as:

Access: $\quad$ The right to enter a defined physical area and enjoy nonsubtractive benefits (e.g., hiking, canoeing, sitting in the sun).

Withdrawal: $\quad$ The right to obtain resource units or products of a resource system (e.g., cutting fire wood or timber, harvesting mushrooms, diverting water).

Management: The right to regulate internal use patterns and transform the resource by making improvements (e.g., planting seedlings and thinning trees)

Exclusion: $\quad$ The right to determine who will have an access right, and how that right may be transferred.

Alienation: $\quad$ The right to sell or lease management and exclusion rights.

The structure of propery rights as we have elaborated can beenriched by drawing unon a general meta-theoretieril framewotk for analyzing institutional arrangements and thange. ${ }^{7}$ The framework allows the analysis of specific property rights systems in dive sse biophysical and fultural environments. It also proposes a/key distipetion between levels of action SYBSTITUTE "A CTION" WITHYANALYSIS"?] and the kules that affect action situations (see Figufe 1).

${ }^{6}$ According to a survey of Forest Departments by the Food and Agriculture Organization, more than 50 countries claim to be moving toward involving user communities in some form in the management of forest resources (FAO 1999).

${ }^{7}$ See Kiser and E. Ostrom, 1982; Oakerson, 1992; Ostrom, Gardner and Walker, 1994; Ostrom, forthcoming. Many of the scholars who have contributed to the development of this framework have been closely associated with the Workshop in Political Theory and Policy Analysis at Indiana University, Bloomington. 
[Figure 1 about here]

Levels of Analysis [SUBSTITUTE "ANALYSIS" WITH "ACTIONS"] and Outcomes

In the most basic operational level situations, individuals iyferact with one another in such a manner as to affect events in the world directly. When a group offwomen harvest fire wood from a nearby forest or a local firm fells trees to be sawn into timber, the structure of incentives that participants face is at an operational level of analysis. Depending on the structure of the situation and interactions among individuals, outcomes can vary dramatically. Forest products may be overharvested or harvested sustainably. The forest, in consequence, mol become degraded or be conserved. Outcomes at the operational level are strongly affectedfy property rights possessed and exercised by those involved. If the users of a forest do not have an/assurance of their right to continue harvesting from a forest, they have little motivation to conserye for the future.

The rules that structure operational situatighs are established in one or more collective choice arenas. Authority at the collective choice level enables the establishment, modification, or elimination of the bundles of operational level property rights/exercised by specific groups of individuals. Determining operational rules is a fundamental exercise of power at the collective choice levels since it results in the allocation of rights and duties to various parfipants.

Collective choice situations are themselves structured by rules determined at a constitutional choice level. Constitutional choice decisions are not just those embedded in some musty document written long ago, but are frequently made by diverse groups. For example, if women in a group come to possess the rights to make collective chofices about the operational rules affecting a particular local forest, the constitutional decision through which they gained these rights could have been made within the village, by a formal government, of as part of a project funded by an international donor.

The analytical distinction between operational level rules, and collective and constitutional choice arenas should not create the ingpression that these correspond to three actual levels of authority or rules in a political or legislative system. A single political body can use operational rules, create them by deliberating at the collective chope level, and may have powers in the constitutional choice arena as well. Or, there may be a number of levels of authority, corresponding perhaps to the village, district, provincial, and the national where specific rules are created and powers are exercised. It is crucial to understand that for any resource, there are some rules that affect day to day use and consumption, others that structure the creation of operational level rules, and still others at a higher constitutional level that affect collective choices.

In a highly centralized regime, almost all authority for making constitutional, collective choice, and operational-level rules is concentrated in a national government. Local officials and citizens are viewed as rule followers, not as fule makers. In regimes that have undergone forms of deconcentration, the authority to make rules at the three levels is still lodged in national government officials even if some of them work in field offices and therefore know more about local circumstances. Forms of decentralization that go beyond deconcentration usually involve local populations and representatives in sharing financial and political powers to design operational level rules at the collective choice level, and in influencing what goes on at the constitutional choice level. Our four case studies indicate that when central governments do not rellinquish some powers of collective and constitutional level decisionmaking to lower level actors the nature of activities and outcomes related to forest management changes relatively little. 
In examining the set of property rights listed above - access, use, management, exclusion, and alienation - it is clear that forms of ownership do not hinge on a single type of property right. Private property is frequently defined as a well-defined right of alienation. Alienation is also often seen as necessary to promote efficient use of resources since property-rights holders otherwise cannot trade their interest in an improved resource system for other resources, nor can someone who has a more efficient use of a resource system purchase a system in whole or in part (Demsetz, 1967). On the other hand, it is assumed that property-rights systems that include the right to alienation will be transferred voluntarily through market exchanges from lower valued uses to their highest valued use. Larson and Bromley (1990) challenge this commonly held view and show that much more information must be known about the specific values of a large number of parameters before judgements can be made concerning the efficiency of a particular type of property right.

In our analysis we find it more useful to define five classes of property-rights holders, as shown in Table 1. "Authorized entrants" are those who possess an operational right to enter and enjoy the natural beauty of the park, but not the right to harvest forest products. Recreational users of parks and forests, worshipers of spirits and deities that are believed to live in forests, or individuals walking through a forest fall into this category.

[Table 1 abouthere]

Those who have both the right to enter and to harvest some forms of products are "authorized users." Operational rules (created in collective choice processes) determine whether there are constraints upon the timing, technology and purpose of use, and quantity of resource units harvested. Operational rights of entry and use may be finely divided into quite specific, and sometimes overlapping "tenure niches" that vary by season, by use, by technology, and by space (Bruce, 1995, Bruce, Fortmann, and Nhira 1993). Operational rules may allow authorized users to transfer access and withdrawal rights either temporarily through a rental agreement, or permanently when these rights are assigned or sold to others (see Adasiak, 1979, for a description of the rights of authorized users of the Alaskan salmon and herring fisheries).

"Claimants" possess the operational rights of access and withdrawal plus a collective-choice right of management. The right to manage includes decisions concerning the construction and maintenance of facilities, the authority to devise limits on harvesting rights, and the ability to enforce limits. ${ }^{8}$ Having at least the bundle of rights associated with being "claimants" is a crucial step in enabling local users to have an effective voice and manage sustainably (Schlager and E. Ostrom, 1993). When local users are able to make their own rules concerning how to limit the timing, location, and technology of use, they are able to begin to learn how to devise rules that fit local circumstances (Ostrom, 1990).

A major problem in trying to devise management rules for an entire country from a central governmental office is that the characteristics of diverse ecological zones can vary dramatically even within a country. The effectiveness of management will then depend on an enormous number and range

\footnotetext{
${ }^{8}$ For studies of how management-related rights are exercised, see Raychaudhuri (1980) for fisheries, Tang (1992) for irrigation, and Varughese ( for forts.

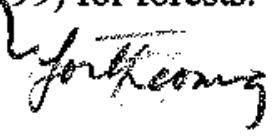


of variables that centralized decision making simply cannot take into account. But the importance of local knowledge has been ignored in much of the forest policy of developing countries. The scientific forestry principles upon which forestry policies are often based are often ineffective without local knowledge that can help to identify scientific findings relevant to a particular location or problem. Further, when national officials are underpaid and understaffed, trying to develop different and effective management plans for a large number of local forests is highly unlikely to be undertaken. Thus, in many cases, the devotion to centrally designed, scientifically informed forest policy has meant open access to forests, and degradation over time since local users do not have more than de facto user rights with no rights to devise rules limiting use or requiring monitoring and other input resources.

"Proprietors" hold the same rights as claimants with the addition of the right to determine who may access and harvest from a resource. Most of the property systems that are called "commonproperty" regimes involve participants who are proprietors and have four of the above rights, but do not possess the right to sell their management and exclusion rights even though they most frequently have the right to bequeath it to members of their family (Berkes, 1989; Bromley et al., 1992; K. Martin, 1979; McCay and Acheson, 1987). Empirical studies have repeatedly found that the rights proprietors possess can be sufficient to make decisions that promote long-term investment and harvesting from a resource. ${ }^{9}$

Thus, we would expect that decentralization programs that actually empowered local users to be proprietors - even without the right to sell these rights to others - generate sufficient incentives on the part of local users that one could expect improved outcomes over time. Because of the right to exclude others, those who jointly hold proprietorship rights are able not only to make rules to manage a resource but to keep others who are not willing to contribute to the costs of management from receiving the benefits. A crucial problem to be solved, however, is how local users can gain some confidence that such rights will not be taken away. This is a major problem in countries where all non-agricultural land has been nationalized in the last century so that local users have lost property rights to use local forests through a sweeping legislative act (Arnold and Campbell, 1986).

"Owners" possess the right of alienation - the right to transfer a good in any way the owner wishes that does not harm the physical attributes or uses of other owners-in addition to the bundle of rights held by a proprietor. An individual, a private corporation, a government, or a communal group may possess full ownership rights to any kind of good including a common-pool resource (Montias,

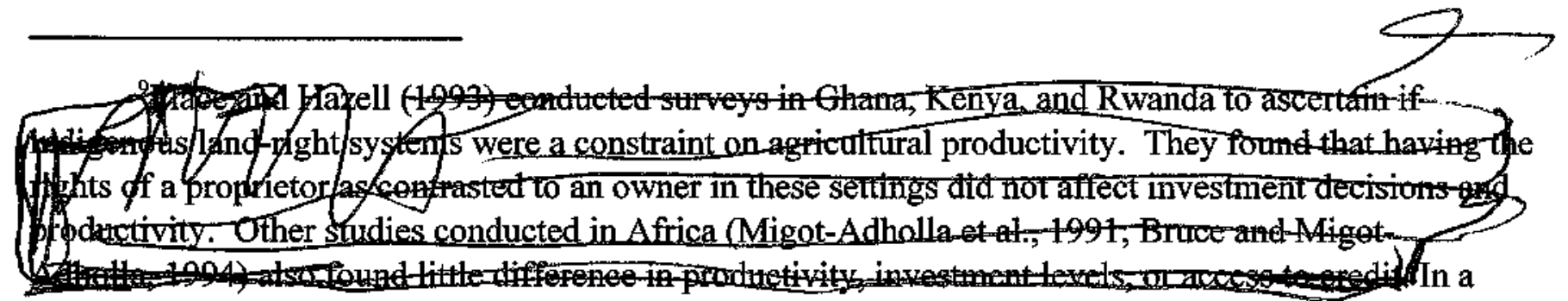
series of studies of inshore fisheries, self-organized irrigation systems, forest user groups, and groundwater institutions, proprietors tended to develop strict boundary rules to exclude noncontributors; established authority rules to allocate withdrawal rights; devised methods for monitoring conformance, and used graduated sanctions against those who do not conform to these rules (Agrawal, 1994; Blomquist, 1992; Schlager, 1994; Tang, 1994; Lam, 1998). In densely settled regions, however, proprietorship over agricultural land may not be sufficient (Feder et al. 1988; Feder and Feeny, 1991). 
1976; Dahl and Lindblom, 1963). The rights of owners, however, are never absolute. Even private owners have responsibilities not to generate particular kinds of harms for others (Demsetz, 1967). Some policy recommendations for complete decentralization recommend that local users be given full ownership rights, but this would be the strongest form of decentralization since then local users could do anything they wanted with the forested land they owned including selling all timber or selling the land itself.

What should be obvious by now is that the world of property rights is far more complex than simply government, private and common property. These terms better reflect the status and organization of the holder of a particular right than the bundle of property rights held. All of the above bundles of rights (entry, harvesting, management, exclusion, and alienation) can be held by a single individual or by groups organized in diverse manners. 1020

Many decentralization proposals assign no more than the operational-level right of being foo authorized users to thosefwhom the program is supposed to benefit. All other significant operational and collective choice rights continue to be held by government officials. Sometimes these officials work in a local office instead of in the nation's capital, but they do not themselves have a long-term interest in sustaining the resource. Obtaining at least some rights to the continued use of a resource may encourage local users to perceive long-term interests in a local resource, but such limited property rights do not establish strong incentives to manage such resources sustainably. Without the operational level right to manage a resource, local users cannot consider various ways of growing and planting seedlings, thinning non-commercial trees for use as firewood, and restricting the grazing of cattle in a forest. Without the collective-choice right to exclude others, local users can still fear that any effort made to limit harvesting will benefit others who also assert a future right to harvest. And, even with these rights, the absence of constitutional choice rights may mean that existing rights of local users can be taken away by distant powerholders without consultation. Therefore, decentralization can be said to have occurred only when governments devolve property rights over resources that conform to the collective and constitutional choice levels. A simple granting of operational level actions in relation to forest resources is insufficient to justify claims of decentralization. ${ }^{11}$

\section{Decentralization of Forest Control in India and Nepal}

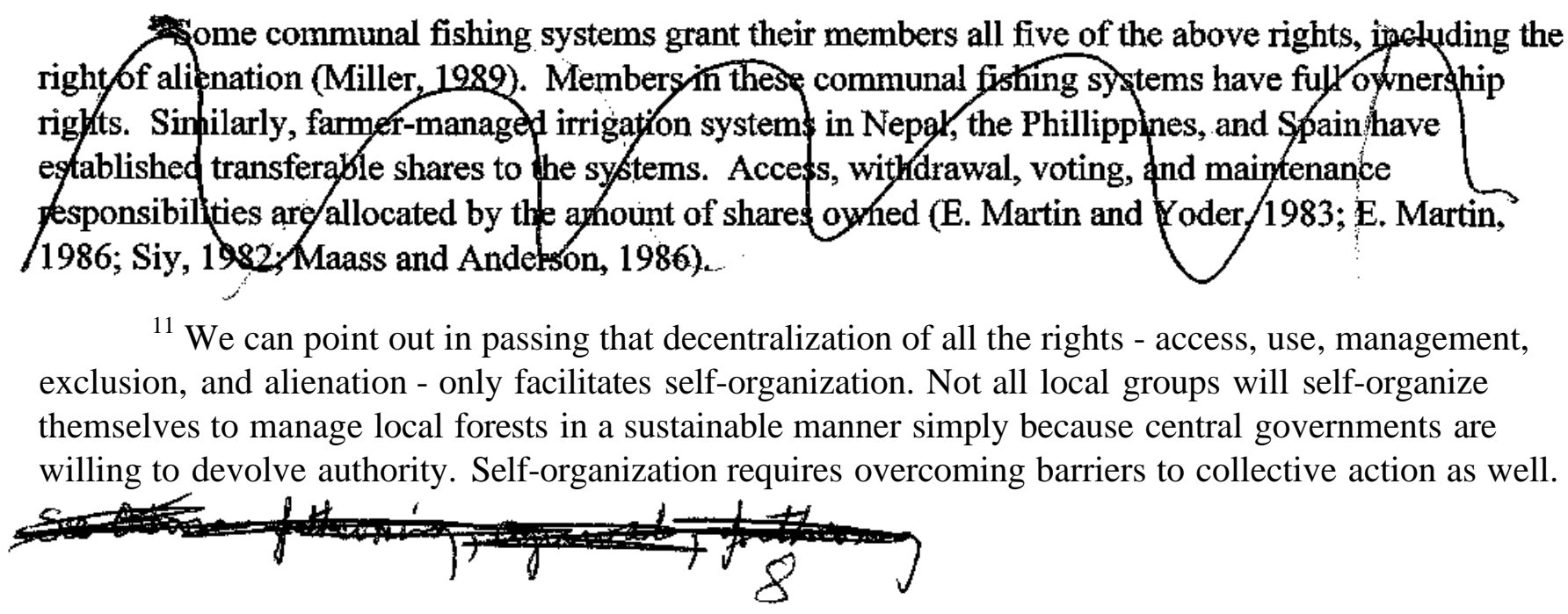


Decentralization of control and management of forest resources around the world takes a number of forms where property rights are concerned. For the most part it occurs under the general rubric of community-based conservation, with varying degrees of control over property granted to communities and their representatives. At one end of the continuum, we can distinguish those circumstances where national governments, in response to a variety of political forces, relax their control sufficiently to allow local users institutional rights corresponding to those of the proprietor. At another end are initiatives that permit users greater rights of access and use (authorized entrant and user), but few claimant or proprietorial rights. In the middle would be a host of other situations in which local residents may be allowed some managerial or decision-making rights, and rights to determine whether others can access or use forests.

The following case studies illustrate the different forms of decentralization of central state control over forests. In Kumaon, India, villagers won significant property rights over forests to become proprietors over large areas of forests through the Forest Councils system. This was the result of a long period of struggle by villagers at the turn of the previous century. In the 1980s, the central Indian government and also many of the provincial governments have initiated a program of decentralization of forest resources known widely/as the Joint Forest Management Program. Despite much wider reach, the results of Joint Forest Management efforts have lagged far behind what a colonial government was willing to devolve in the 1920 and the 1930s. In Nepal's Middle Hills, a widespread program of devolution of forested areas under the Community Forestry program has created thousands of active forest user groups. But in the Terai region of Nepal, where the government has sought to decentralize control over National Parks and Protected Areas and involve residents in the Parks and People Program, the results have fallen far short of what might be called effective decentralization. The four case studies together illustrate the elements we have highlighted in a property rights framework to analyze decentralization. They also provide some indication of when decentralization is likely to be more successful.

Decentralization and Forests in Kumaon in India

The forest councils of Kumaon, created in 1931 through an act of decentralization by the British colonial state, constitute one of the oldest surviving examples of formal collaboration between the state and communities for resource management. Local level collective action by villagers, and bureaucratic politics within the state were critical to the formation of the forest councils.

Origins, actors, and their interests

Between 1911 and 1917, the British golonial state transferred more than 3,000 sq/miles of forests in Kumaon to the Imperial Forest Department (KFGC 1921). The government bad made a number of inroads between 1815 and 1910 to curtail progressively the area of forests fhat local communities used. in incursions raised the special ire of the villagers. Their grievances were particularly acute because the elaborate new rules specified strict limits on lopping/and grazing rights, restrictedfuse of non-timber forest products, prohibited the extension of cultivation, the labor extracted from the villagers, and the number of forest guards.

The new laws goaded villagers into widespread protest. The best efforts of government officials failed to convince the villagers that the forests belonged to the government. The incessant, often violent, protests forced the government to appoint the Kumaon Forest Grievances Committee (KFGC) 
to look into the local "disaffection." Comprising government officials and local political leaders, the KFGC examined more than 5,000 witnesses from all parts of Kumaon. It used the resulting evidence to make two major recommendations 1) dereserve the larger part of the newly created Reserved Forests , and 2) lay the foundations for community forests that would be managed under a broad set of rules framed by the government, but for which villagers themselves would craft the specific rules for everyday use to fit local conditions.

The government took both recommendations seriously. At first, it reclassified Reserved Forests that had been taken over by the Forest Department between 1911 and 1917 into Class I and Class II forests. Class I Reserved Forests were all transferred to the revenue department and, in time, could come to be controlled by villagers. Class II Reserved Forests remained under the control of the Forest Department. The government also passed the Forest Council Rules of 1931. These rules permitted village residents to create forest councils and bring under their own control forest lands that had been transferred to the Revenue Department as Class I Reserved Forests and Civil Forests.

The division of forests into two categories--Class I/Civil Forests under the control of the Revenue Department and Class II Forests under the control of the Forest Department-resulted in part from the inter-departmental rivalry that was sparked into being by the creation of the Imperial Forest Department in 1878, and by the passing of a huge swathe of territory under its control in the name of the protection of forests. The increasing control of the Forest Department over vast stretches of land, and the revenues it generated by auctioning timber from the lands under its control rivaled and outgrew the revenues from land. The transfer of all the Class I forests to the Revenue Department was the outcome of a bureaucratic struggle wnd protests by villagers for greater access to and use of their forests fed into this struggle. Villager protests helped the case for the transfer of a significant proportion of territory back to the Revenue Department, and from the Revenue Department to villagers in the form of forests managed by village level councils. The passing of managerial control into the hands of village residents has led to more effective enforcement of forest-related regulations.

\section{Degree of decentralization of property rights}

Nearly 3,000 forest councils today formally manage and control about a quarter of the forests in the three districts of Kumaon: Nainital, Almora, and Pithoragarh. The Forest Council Rules of 1931, as amended in 1976, specify state-defined limits to local autonomy. Villagers cannot clear fell the forestor impose fines beyond a specified amount They can raise revenues only through certain limited sources, and they must take recourse to established legal procedures to resolve conflicts. Conflicts over interpretation and application of rules are resolved by district and provincial level revenue/judicial authorities. But Collectively, the Forest Council Rules constitute more a framework for the management of forests than a defining straitjacket. Rural residents, through their elected forest councils, possess substantial powers to create concrete restrictions to prevent certain types of forest use and facilitate others. Villagers vote to elect between 5 and 9 council members and the council leader. Councils in many of the villages meet frequently. Their members discuss, craft, and modify specific rules that will govern withdrawal of forest products, and create monitoring and sanctioning mechanisms in an effort to enforce the Forest Council Rules as well as locally specific rules crafted by councils. Councils select guards, fine rule breakers, manage finances, and maintain records of their meetings, accounts, and local rule infractions. In many of the cases, guards selected by councils are paid by contributions from village households.
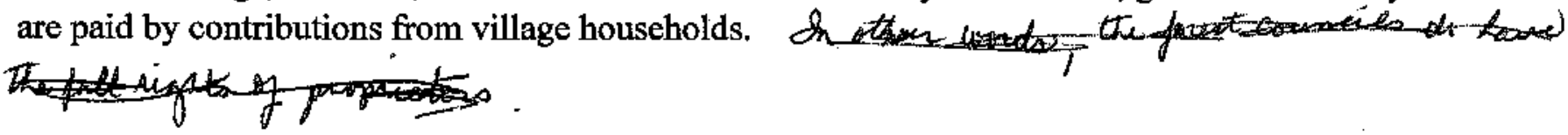
The Forest Council Rules also provide for support to the councils from the revenue and the forest departments to facilitate rule enforcement and the maintenance of vegetation in the forests. Over the past sixty years the relationship that has evolved between village uses and the forest and the revenue departments has been one in which villagers and their councils have increasingly come to depend on government departments for activities related to the management of their forests. Elections to the forest council are held under the supervision of the forest council inspector. The council is expected to meet regularly, keep records of meetings and maintain accounts. Whereas Revenue Department officials underwrite the enforcement of rules, the forest department coordinates the commercial harvest of forest products from community forests and provides technical assistance to develop them. Before the council can sell any of its timber or resin, it must seek approval from the relevant authorities in the forest department. Like the interactions with the Revenue Department officials, these can take a long time because of other duties which receive greater priority.

\section{Outcomes}

The above description of the rights to forest management in Kumaon shows that the rural residents of Kumaon not only have the rights to access and use local forests, but they can also exercise claimant and proprietor rights. The forest councils' ability to harvest firewood for commercial purposes and their access to markets for timber is mediated by the Forest Department. But otherwise the councils control the use of their forests to a large degree.

Studies of forest councils' effectiveness in protecting forests show the importance of managerial responsibilities related to exclusion, monitoring, and enforcement (Agrawal and Yadama 1997). The forest councils can be seen as locally situated partners in the management of forests, subordinate to the employees of the forest and the revenue department, but with substantial control over local management. Their asymmetric relations with government officials cast the officials into the role of arbiters in case of disputes between villagers and forest council office holders. Forest users can also question the authority of the councils implicitly by not limiting their harvests of forest resources. They also do so more explicitly by contesting the fines imposed by the councils. In each of these situations, the councils need to invoke the cooperation of government officials, simultaneously demonstrating their links to the state, their weaker position in this managerial relationship, and their relative autonomy in everyday management.

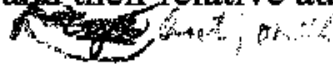

The condition of vegetation on council managed forests compares favorably with the best forest lands in the hills which are under the control of the forest department. The council managed forests are in far better condition than those managed by the Revenue Department. Overall, the experiment to decentralize forest management in Kumaon seems to have been a significant success by most measures of decentralization.

\section{Joint Forest Management in India}

Since the founding of the Forest Department in several states of India in the $1860 \mathrm{~s}$ and the passage of the first Forest Act in 1978, the Indian state has attempted to define and allocate property rights over forests ever more precisely. The major goal of defining property more precisely has been the generation of higher levels of revenues. But where attempts to control forests have led to social unrest or protests, the Indian state, right from the colonial period, has also shown itself capable of retreating and sharing benefits and some revenues with new claimants.Forest Councils in Kuamon are a well

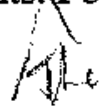

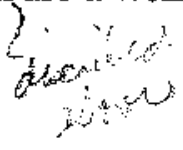


researched example, but other instances are available in Kangra (Agrawal 1994), Karnataka (Gadgil and Guha 1995), Bastar in Madhya Pradesh (Sundar 1997), and the Dangs in Gujarat (Skaria 1999). It would be fair to conclude that although many instances of cooperation between government and village populations to protect and manage forests can be cited, historically the more familiar relationship is one of hostility between the forest department and forest dependent groups.

\section{Origins, actors, and their interests}

Joint Forest Management, with its objective of better management of forests through cooperation between the Forest Department and village communities, marks an important shift in the strategy of environmental conservation in India (Kolawalli 1995, Krishnaswamy 1995). The impetus for a nationwide program that could lead to an altered relationship between the state and village residents has come from several sources. Among these are a sustained critique of forest policy by environmentalists, examples of successful community-based forest management in the states of West Bengal and Orissa, the increasing difficulty that the Forest Department faced in enforcing coercive forest conservation, efforts of many NGOs and social movement actors to influence government policy toward greater participation, and pressures and monetary inducements from multilateral and bilateral donors like the Ford Foundation, SIDA, and the World Bank (Sundar 2000). One of the main reasons why the Indian central government has been willing to afof communities into the management process has been the limited success of the Forest Department in protecting forests under its control. For example, in the early 1980s, satellite pictures of vegetation cover revealed that although the forest department controlled about $25 \%$ of India's land, only about $11 \%$ had significant cover. The different state governments have had other reasons as well, among them, aid from donors for community-based conservation.

The National Forest Policy of 1988, government orders by many states, and the Government of India policy instructions of 1990 are the formal instruments that have launched Joint Forest Management (Arora 1994). By 1998, 20 out of 25 Indian states had passed resolutions to encourage the setting of village-level forest protection committees. At this point nearly all the Indian states are involved.

\section{Degree of decentralization of property rights}

In most states the forested area to be covered through Joint Forest Management is land that has less than $40 \%$ crown cover. The primary mechanism of decentralization are village-level Forest Protection Committees. Although informal local bodies had managed forests in many parts of India even before Joint Forest Management, now it is Forest Department officials who register existing committees and often initiate new committees. Officials are also empowered to dissolve the committees (Poffenberger and Singh 1996). Because of the substantial powers Forest officials have in forming, registering, and dissolving local committees, many villagers perceive the process to be arbitrary and biased.

For the most part, the members of forest committees members of forest committees gain the benefit of using the non-timber forest products from their village forests, and a share of the proceeds from the sale of timber once forests have matured. Villagers do not have the right to harvest timber products, unless the wood is dry or has fallen to the ground. In some cases, their share of the proceeds from timber harvests is limited, and has been reduced after successful protection (Mahapatra 2000). 
The degree to which villagers can frame their own rules of use and management is significantly shaped by Forest Department officials. Indeed, Forest Department interventions in day-to-day management of village forests are often quite high (Sundar and Jeffery 1999). Villagers clearly have the responsibility to protect trees and vegetation and the ability to allocate non-timber benefits within the community. But where more significant issues are at stake as transfer of power to villagers, formation of forest protection committees, share in timber sales, or ability to negotiate rule changes, villagers are highly constrained in their ability to act (Kumar 2000, Sundar 2000).

\section{Outcomes}

There are no comprehensive assessments of what has resulted from Joint Forest Management across the forested landscape in India (but see Jeffrey and Sundar 1999, Poffenberger and McGean 1996). According to a recent study (Khare et al. 2000), however, protection committees now cover nearly 70,000 sq kms, more than $10 \%$ of Indian forests. An earlier analysis estimated nearly 24,000 protection committees to be in existence (Agarwal 1997). There are remarkable variations in accomplishments, but it is likely that Joint Forest Management has provided many villagers with increased legitimate access to important livelihood resources. Increased access to non-timber resources has occurred in tandem with continuing efforts by the Forest Department to control silvicultural aspects of forestry and commercial revenues from sale of timber. Within communities, participation and allocation of benefits varies greatly by caste, gender, class, and occupation. For example, because of membership rules that specify a single member from an household to the forest protection committee, women often have little say in the limited rights of management that villagers exercise. Finaly, an accurate assessment of the program is difficult because of conflicting objectives of foresters who most often see it as a means to protect forests, and villagers who view it is a solution to problems of shortage of ffrewood and fodder, or as a way to improve income.

Indeed, many of the outcomes of Joint Forestry Management maý appear paradoxical. The Forest Department that traditionally favored commercial timber species/and centralized management has now also begun to promote the planting of indigenous species, and|solicit limited participation. International organizations have poured funds into a participatory environmental management scheme that, like most many such schemes has not managed to move too far.beyond populist idioms. And finally, by incorporating a large number of forest protection committees within its own ambit, the Forest Department has successfully recovered some measure of control and protection over degraded lands that earlier produced little timber or even non-timber products.

\section{Community Forestry in Nepal}

Perhaps the first systematic effort to centralize forest management in Nepal took place in 1957 when the government nationalized all forests in Nepal. This assertion of control was cemented through a series of measures between 1961 and 1970 when the state tried to curtail even the use rights of rural residents in forests. In the absence of effective monitoring and enforcement systems, however, the new laws had perverse effects. They undermined existing local systems of management and led to widespread deforestation as people came to view forests as state property. The overwhelming evidence on deforestation showed that the existing policy needed rethinking.

Origins, actors, and their interests

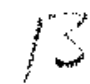


Today Nepal is often seen as a leader among developing countries in setting conservation goals and priorities, and creating progressive programs and legislation related to resource management and conservation (Heinen and Kattel; 1992). New steps toward decentralization of forest control began to take place in the late 1970s. The precursor of current community forestry legislation were the Panchayat Forest Rules of 1978 and the Community Forestry program of 1980. The limited conservation objectives of these initiatives were revised with the realization by the government that deforestation in Nepal Hills was approaching epidemic proportions. The pace of reforms accelerated with the widespread movement for democratization, and the restoration of democracy after 1990. A number of earlier community forestry programs launched by specific donor agencies also helped in the formulation of new legislative measures. The current framework for community forestry legislation is represented by the Master Plan for the Forestry Sector in 1989, the Forest Act in 1993, and new Forest Regulations of 1995. Under the impact of these new pieces of legislation, the area of forests managed by local user groups and the number of these groups has increased exponentially under the nat

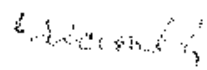

\section{Degree of decentralization of property rights}

The major objectives of the new legislation are to provide forests to willing community groups, especially in the hill areas, and establish and promote community plantations in open and degraded areas. Community user group members are identified by the District Forest Officers on the basis of house to house visits. These user groups then prepare their own constitutions that govern day-to-day "functioning and management. Following the demarcation of a forested area that can be handed over to a community, a 5-year operational plan is prepared for the forest. User groups plays a direct role in preparing and implementing the plan, with assistance from the Forest Department. The District Forest Officer can hand over any part of a national forest to a user group in the form of a community forest entitling it to develop, conserve, use, and manage the forest, and to sell and distribute forest products by independently fixing the prices in the market. User groups can thus legally use their forests for subsistence, cultivating non-timber forest products and growing trees, and harvesting forest products for commercial processing and sale. Users are not permitted to clear the forest for agricultural purposes. But control over commercial profits from sale of timber products is already a major departure from forestry policies around the world

Executive committees of 10 to 15 members, elected by the general body of the forest user group, are the norm, and are entrusted with the management of the forest. These tasks include protection of the forest, either directly or by a guard the user groups appoints, allocation of benefits from the forest, steps to improve the condition of vegetation cover, and sanctioning rule breakers. Rural residents in many areas have begun to generate substantial benefits from their community forests, including cash revenues. Revenues are not taxed, but user groups are required to spend $25 \%$ of all cash income on collective development activities aimed at the user group membership.

\section{Outcomes}

By 1999, the new legislation had led to the formation of 8,500 community forest user groups comprising nearly a million households. These user groups were managing more than $6,200 \mathrm{sq} \mathrm{kms}$ of forests. This is about $10 \%$ of the total forest area of Nepal. Unofficial estimates of these numbers are even higher. New user groups are being formed at the rate of nearly 2000 a year and they are now

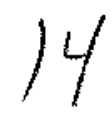


active in 74 out of 75 districts of Nepal. In some areas of Nepal hills, a slow reversal of earlier deforestation can also be witnessed (Mahapatra 2000: 8).

The nature of property rights that community forest user groups have received in Nepal places them in the category of proprietors. They are able to use all the products from their forests, buy and sell in markets, manage how the forest is to be used, and finally, create collective and constitutional level rules that would affect the nature of management. But a potential problem is the question of succession. At present most groups, mainly because they have been formed relatively recently, have the same leaders that were selected at the time of their creation. But as the groups grow older, issues of who will lead the group, and how transitions will occur will become increasingly important.

An important development in Nepal community forestry is the emergence of a nationwide federation of community user groups (FECOFUN or Federation of Community Forestry Users of Nepal), that seeks to lobby the government on behalf of its members, and to disseminate information about community forestry more widely. It has already had occasion to actively protest against government signals that user groups' rights to commercial profits from their forests may not be available in the Terai region of Nepal. The forests in the Terai have far more monetary value than those in the hilly regions. Indeed, efforts by the government to contain commercial use of community forest products only to the Hill regions of Nepal signify the limits of the willingness of forest departments to devolve control.

\section{The Parks and People Program in Nepal's Terai}

Decentralization of forest rights in Nepal's Terai, especially in the buffer zone of the national parks is a somewhat different story in comparison to Community Forestry. Beginning from protection of wildlife in royal hunting reserves, prior to 1960s, Nepal has created an extensive network of 15 national parks, wildlife areas, hunting reserves, and conservation areas that cover nearly $15 \%$ of the country's total area. Of this network of protected areas, five are in the Terai. These five protected areas face the greatest problems related to conservation because each of them is in close proximity to significant human populations.

\section{Origins, actors and their interests}

Nepal's Department of National Parks and Wildlife Conservation came into being in 1980, with authority to administer the protected areas system in Nepal. It is part of the Ministry of Forestry, along with the Department of Forestry. The Parks and People Program was established after negotiations among officials in the Ministry of Forestry and the United Nations Development Program (UNDP). The area covered by the Program is the buffer zone of the five National Parks and Wildlife Reserves in Nepal's Terai, and comprises nearly 2,000 sq kms with a population of more than 600,000 people. An important factor in the launching of the Program is support from the UNDP. Local residents were unhappy with the coercive forms of protection that were used for conservation of wildlife and forest resources in the protected areas. But there have been no systematic efforts at collective protests, nor any attempts to pressure the government into changing its protected areas related policies.

\section{Degree of decentralization of property rights}

To address the human-nature conflicts in relation to protected areas, the Parks and People Program aims at three objectives. One, it attempts to develop alternatives to the use of park resources

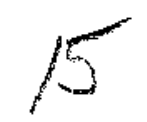


for neighboring households; two, it seeks to devise compensation mechanisms for local communities in exchange for their exclusion from resources upon which they relied prior to the formation of the protected area in question; and three, it tries to create incentives for local populations to change their actions in relation to the protected areas. Development of the buffer zones that "separate a protected area from direct human or other pressures and provides valued benefits to neighboring rural communities" (Nepal and Weber 1994: 333, Ishwaran and Erdelen 1990), is a key element of the conservation strategy in the Parks and People Program.

To pursue these objectives, the Parks and People authorities have attempted to create user groups in the buffer zones of the protected areas. The Warden of a protected area, or other members of the Parks and People Program can constitute user groups in the buffer zone to coordinate the management of fallen trees, firewood, fodder, and other grasses. Members of the user groups can use forest resources in buffer zone for subsistence, and also for commercial sales. For specified times during the year, buffer zone residents are permitted to enter the protected area itself, and harvest products such as thatch grass and firewood, and in some cases, graze their animals. Typically, the period for which they can harvest thatch grass, used for roofing, varies between ten and fifteen days in a year. Rules related to harvesting of firewood and grazing of animals are quite strict.

Of the total income earned through sales of forest products, 30 to 50 percent can be used for community development in consultation with local agencies and community members. Parks and People Program officials had created approximately 400 community user groups in the buffer zones of the Parks by the end of 1999. Although these groups have limited rights of access and use in the forests, they have little control over how forest resources in the protected area are allocated. Most rules continue to be crafted by protected area officials without the involvement of local residents. Thus villagers in the buffer zone do not possess any rights of collective or constitutional choice to create rules at the operational level. Nor are they involved in the enforcement of the rules.

\section{Outcomes}

The Program has led to an increase in the number of forest department officials, development offices, and projects related to social and economic change in the buffer zone. The politics and procedures that have produced these changes have primarily been born within the Nepali government and foreign aid agency programs, rather than being prompted by local demands. Local interactions among residents near protected areas have been counted as relevant mainly because of perceptions among government officials and aid agency personnel that consumption pressures generated by the poor have the potential to adversely affect protection of natural resources $\left(a_{5}\right.$ now

The main arena in which decentralization has occurred as a result of the Parks and People Program is that local users have been permitted entry into and use of park resources. They have had little influence on the nature of management of forest resources, or on conservation outcomes. Conflicts between residents and Park officials still occur regularly, and are unlikely to diminish without substantial change in existing institutional arrangements, or reallocation of the property rights that residents currently exercise. In this sense, the major change in the status of the buffer zone residents has been that from being illegal users of park resources, they have now become authorized entrants and users.
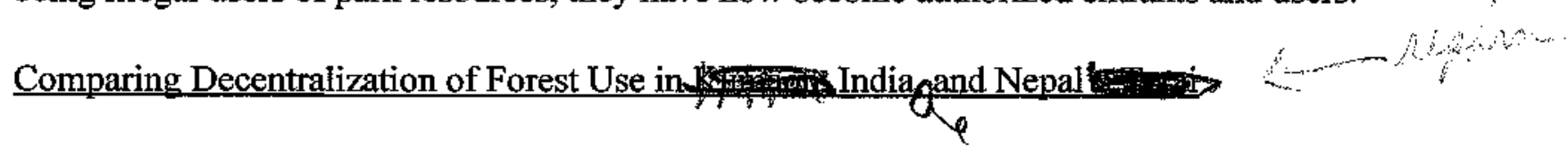
Decentralization of forest resources in the four cases differs in terms of origins, actors involved, the extent to which sub-national actors have come to exercise new property rights, and outcomes related to forests. Overall, the greatest levels of decentralization seem to have occurred in Community Forestry in Nepal, and the forest councils of Kumaon The Parks and People Program in Nepal, despite claiming to be pursuing participatory decentralization, has devolved such limited property rights that it can scarcely be classified as a case of decentralization. Joint Forest Management in India is spread over the largest area of the four cases, and has highly variable outcomes, but overall, the Forest Department continues to exercise significant managerial control over local actors. As a result, the degree of decentralization of property rights in this case falls somewhere between the case of the forest councils of Kumaorgand the Parks and People Program in Nepal's Terai. Table 2 summarizes the discussion of the four cases and highlights their differences.

[Table 2 about here]

High levels of local collective mobilization meshed with interdepartmental conflicts within the British colonial state to facilitate the birth of the forest councils of Kumaon. Protests by hill residents helped the Revenue Department gain control over a significant proportion of forest land. Through the creation of a new set of officials to supervise the forest councils created by villagers, the Revenue Department also gained a measure of control over local activities. It is unlikely that by itself, local collective action would have yielded decentralization. In the case of community forestry in Nepal and Joint Forest Management.in India, there were no significant pressures locally for decentralization, but $\omega$ there were effective fobbying groups national on much ctiticism of existing government policy together why clear evidence that the Forest Department had to change its policies drastically if environmental conservation was to be successful. In Nepal's Terai, government officials were able to launch the Parks and People Program in the name of decentralization. Ifothe chief motivation behind this program seems to be availability of funds from a donor organization, not local protests nor clear evidence of failure of existing coercive conservationist strategies.

It is not surprising, therefore, that Kumaon villagers and rural residents who are members of community forestry user groups in Nepal have gained significantly wider latitude in the property rights they exercise over forests in comparison to the rights exercised by villagers in the buffer zones of the Protected Areas in Nepal's Terai, or even those involved in Joint Forest Management in India. In Kumaon, villagers have clear rights to access and use forest products, and almost complete control over management of their forests. The state has placed some limits on managerial discretion, such as prohibiting clear felling, or the involvement of the Forest Department in commercial sales, but in daily management villagers have a free hand. They are entitled to exclude others from their forests, and can even buy, sell, bequeath, to others the use and access rights they hold.

The Community Forestry initiative in Nepal grants to villagers even more far reaching property rights. In addition to all the rights that forest councils of Kumaon enjoy, Nepal villagers can also buy and sell timber, and retain the revenues themplety for themselves They are not required to involve the Forest Department or any other government gficials in market transactions. The one limitation of the initiative is in relation to leadership andsuccession at the local level since existing rules are unclear on this subject and over time existing legders can entrench their positions. Furter.

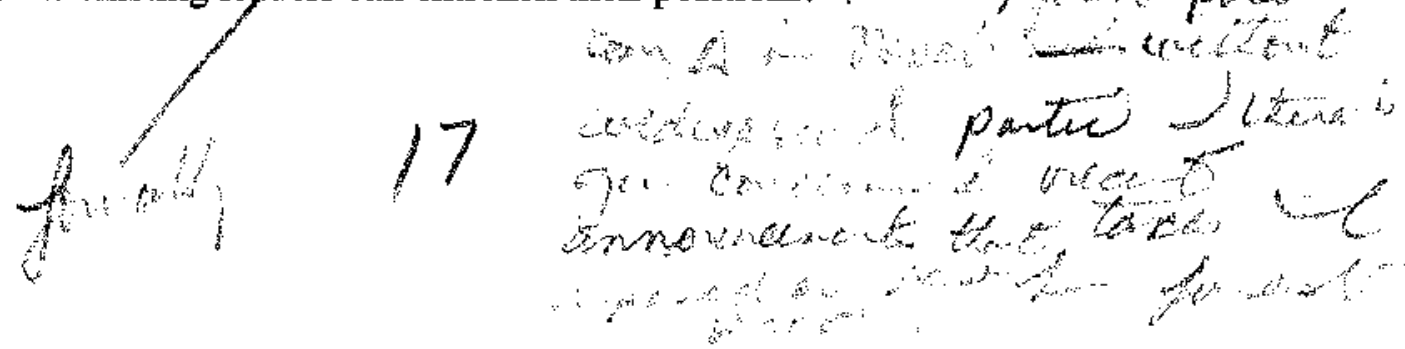


Joint Forest Management in India grants to villagers the property rights of access and use, and management, but in actual functioning of the forest protection committees, there is significant intervention from forest department officials. In addition, there is no security of tenure of the committees since they have to be registered by Forest Department officials, who also have the power to dissolve a committee. Because of these limitations, the degree of decentralization of property rights in Joint Forest Management conforms only to that of claimants.

Similarly, user groups in the buffer zones of the protected areas in Nepal's can only claim to have somewhat attenuated use and access rights in the forest in the protected areas. They have almost no managerial discretion, and few powers of exclusion or alienation. Collective and constitutional choice authority has been retained by the Department of National Parks and Wildlife, and the Parks and People Program officials.

The evidence on outcomes related to forest conditions and changes in forest conditions are somewhat preliminary and sketchy to permit a clear conclusion at this point. On the whole, it seems likely that decentralization of property rights over forests to local users results in improvement of forest conditions. Recall that in Kumaon the Forest Department had kept the best land to itself as Class II forests, and only transferred the somewhat more fragmented and often more degraded patches of forests to the Revenue Department for eventual management by forest councils. Yet, today the condition of forests on land held by the forest councils compares favorably with that of Forest Department managed lands. Similarly, in Nepal hills where just about two decades ago many scholars were raising an alarm about the degradation of forests (Eckholm 1976, for a review see Ives and Messerli 1989). Some improvement in the condition of vegetation is already visible.

\section{Conclusion}

This paper began with the objective of answering two questions about decentralization: What role do local populations play in ensuring that these types of property rights are actually devolved? And what types of property rights must be devolved to local populations for effective decentralization?

The evidence we have on the first question is somewhat mixed. In one of our cases - forest councils of Kumaon - the effective mobilization of local actors was instrumental in the initiation of decentralization. In the case of the Parks and People Program, there were no local demands, and there was no effective decentralization. But in two cases, where we witness significant levels of decentralization - Community Forestry in Nepal and Joint Forest Management in India - local actors, even without having mounted a widespread social movement or nationwide organization, enjoy significant property rights as a result of decentralization initiated by state actors. We must conclude that active participation of local actors is not a prerequisite for decentralization programs to be launched. State actors can initiate decentralization programs on their own. Their efforts to decentralize are likely to be more meaningful when local actors, or other interested parties such as international donors and/or lobbying groups (in our case, environmental critics of existing government policies), also create pressures toward decentralization. It is noteworthy that in the case of the Parks and People Program, the pressures for decentralization were generated from outside the government, through the intervention of an international donor agency. In the case of both Joint Forest Management in India and Community Forestry in Nepal, there were sufficient numbers of actors within the government who were active in pursuing decentralization, even if no clear pressures from local populations were visible.
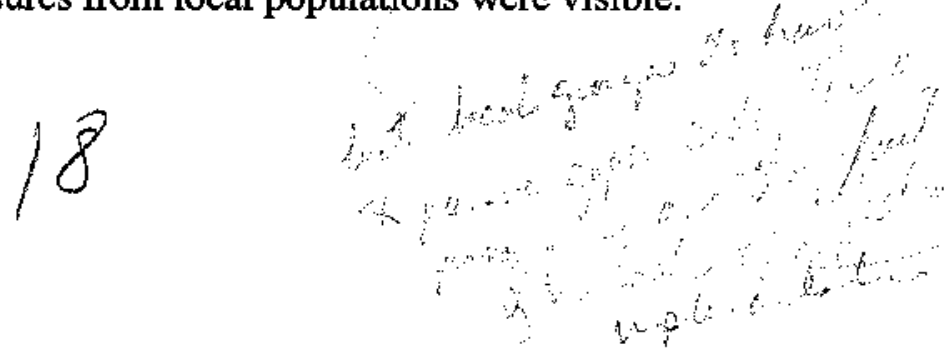


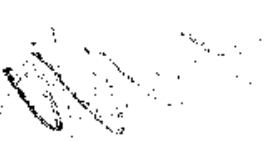

However, it is a different story when we come to the issue of maintenance of decentralized property regimes. For continued existence of decentralized control over resources, active participation of local actors seems to be quite necessary. Nepal's Community Forestry Program has seen the emergence of a national level networking organization, FECOFUN, that is prepared to voice protests against efforts of the Ministry of Forestry to roll back the process of decentralization. Neither the forest councils of Kumaon, nor the protection committees formed via the efforts of Joint Forest Management in India have similar organization or representation. The emergence of such macro-level networks and organizations is likely to be crucial to ensure that decentralization processes, once initiated, are not retracted.

The evidence on the second question is more conclusive. The case studies confirm that for effective decentralization, it is necessary for local users and their representative institutions to possess property rights that transform them into claimants and proprietors. The delegation of only the operational level rights of access and use of forests and forest products does not produce any change in either the condition of vegetation, or in the relationships between state and community actors. The decentralization of control over forests in Kumaon has meant that local residents in the region have come to interact in very different ways with local and government officials as compared to the past. There is significant enforcement of locally crafted rules, and variations in the conditions of forests are primarily a result of micro-level variations in institutional and bio-physical factors. A similar story can also be told for Nepal's Community Forestry Program. Rural residents have come to mange their forests themselves, the nature of their relationships with government officials has changed as they experience the freedom of acting without the interventions of forestry officials in every stage of forest use and management. In the case of Joint Forest Management, the results are sufficiently variable that a blanket assertion of improvement for the better would be hasty at best. The situation is quite different, however, in Nepal's Terai. Villager participation in the Parks and People Program, and in the use and management of forests in the protected areas is limited.

The findings of our empirical study, thus, match the theoretical expectation that when local users do not come to exercise any significant control after decentralization over collective and constitutional * level choices related to rule design, management, and enforcement, the impact of decentralization is likely to be quite limited. have an impact on forest use and conditions. More specifically, decentralization should allow local users and their representatives at least the rights to manage resources and make decisions about resource use and the exclusion of others from the use of resources for decentralization to produce an impact.

To conclude, successful decentralization initiatives on forests are difficult to accomplish without the existence of state actors who see some of their interests being fulfilled by decentralization processes. Decentralization implies changes in property rights over resources that gain local users rights and capacities to make operational rules. As importantly, decentralization initiatives should allow users to make collective and constitutional choices. Further, the likelihood of success is enhanced by promoting the conditions that generate self-organization among local groups. As the examples of the Kumaon forest councils and Community Forestry in Nepal make clear, only with some level of organization and pressure from local groups are decentralization processes likely to move beyond the control of elite actors. 


\section{FIGURE 1}

\section{LEVELS OF ANALYSIS AND OUTCOMES}

\section{Individuals' Actions Taken that Directly Affect \\ State Variables in the World}

OPERATIOHAL SIIUATTONS

(Provis jom, Production, Distrbution, Appoppiation, Assignment, Consumption)

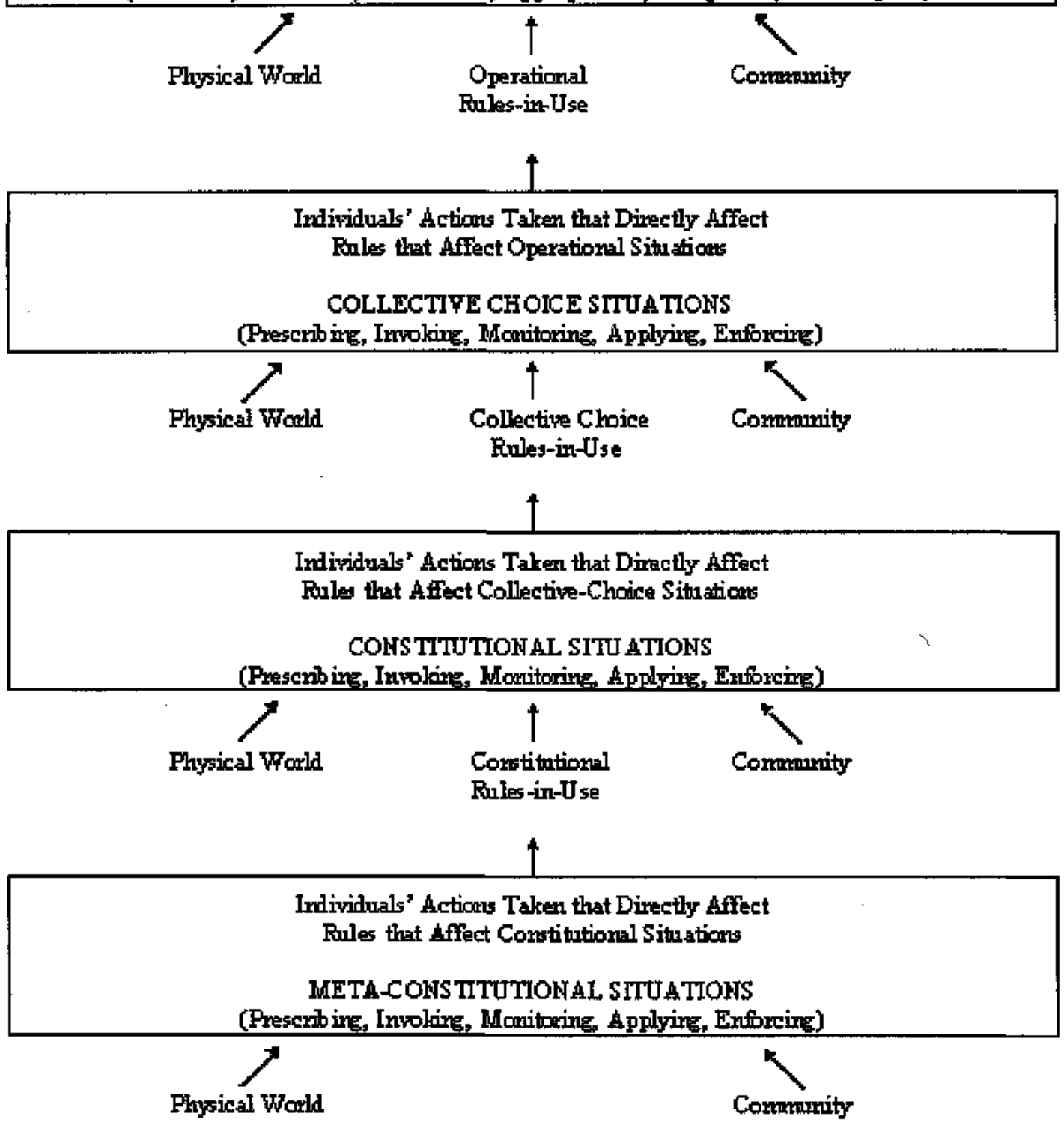


Table 1: Bundles of Rights Associated with Positions

\begin{tabular}{lccccc}
\hline & Owner & Proprietor & $\begin{array}{c}\text { Authorized } \\
\text { Claimant }\end{array}$ & $\begin{array}{c}\text { Authorized } \\
\text { User }\end{array}$ & $\begin{array}{c}\text { Authorized } \\
\text { Entrant }\end{array}$ \\
\hline Access & $\mathrm{X}$ & $\mathrm{X}$ & $\mathrm{X}$ & $\mathrm{X}$ & $\mathrm{X}$ \\
Withdrawal & $\mathrm{X}$ & $\mathrm{X}$ & $\mathrm{X}$ & $\mathrm{X}$ & \\
Management & $\mathrm{X}$ & $\mathrm{X}$ & $\mathrm{X}$ & & \\
Exclusion & $\mathrm{X}$ & $\mathrm{X}$ & & & \\
Alienation & $\mathrm{X}$ & & & & \\
\hline
\end{tabular}

Source: E. Ostrom and Schlager (1996: 133). 
TABLE 2: Comparing Decentralization of Forest Control in India and Nepal

\begin{tabular}{|c|c|c|c|c|}
\hline $\begin{array}{l}\text { Axes of } \\
\text { Comparison }\end{array}$ & $\begin{array}{l}\text { Forest Councils, } \\
\text { Kumaon }\end{array}$ & $\begin{array}{l}\text { Joint Forest } \\
\text { Management }\end{array}$ & $\begin{array}{l}\text { Community } \\
\text { Forestry, Nepal }\end{array}$ & $\begin{array}{l}\text { Parks and People } \\
\text { Program, Nepal }\end{array}$ \\
\hline $\begin{array}{l}\text { 1. Macro Level } \\
\text { Politics }\end{array}$ & $\begin{array}{l}\text { - No donor } \\
\text { pressures; } \\
\text { - High interest } \\
\text { among state } \\
\text { actors in } \\
\text { decentralization }\end{array}$ & $\begin{array}{l}\text { - High donor } \\
\text { pressures } \\
\text { - Some interest among } \\
\text { state actors in } \\
\text { decentralization }\end{array}$ & $\begin{array}{l}\text { - High donor } \\
\text { pressures } \\
\text { - Some interest } \\
\text { among state actors } \\
\text { in decentralization }\end{array}$ & $\begin{array}{l}\text { - High Donor } \\
\text { pressure to create the } \\
\text { Program; } \\
\text { - No inter- } \\
\text { departmental rivalries }\end{array}$ \\
\hline $\begin{array}{l}\text { 2. Collective } \\
\text { Action }\end{array}$ & $\begin{array}{l}\text { - Local collective } \\
\text { action resonates } \\
\text { with inter- } \\
\text { departmental } \\
\text { rivalries }\end{array}$ & $\begin{array}{l}\text { - Donor pressures } \\
\text { match interests of } \\
\text { state governments } \\
\text { - Low levels of local } \\
\text { collective action, } \\
\text { match the interest of } \\
\text { central government } \\
\text { actors }\end{array}$ & $\begin{array}{l}\text { - Donor pressures } \\
\text { and the low levels } \\
\text { of local collective } \\
\text { action match the } \\
\text { interests of central } \\
\text { government actors }\end{array}$ & $\begin{array}{l}\text { - No collective action } \\
\text { at local level } \\
\text { - Little connection } \\
\text { with higher levels of } \\
\text { politics. }\end{array}$ \\
\hline \multicolumn{5}{|l|}{$\begin{array}{l}\text { 3. Property } \\
\text { Rights }\end{array}$} \\
\hline $\begin{array}{l}\text {-- Rights to } \\
\text { Access }\end{array}$ & $\begin{array}{l}\text { Granted to local } \\
\text { groups }\end{array}$ & $\begin{array}{l}\text { Granted to local } \\
\text { groups }\end{array}$ & $\begin{array}{l}\text { Granted to local } \\
\text { groups }\end{array}$ & $\begin{array}{l}\text { Granted to local } \\
\text { groups }\end{array}$ \\
\hline $\begin{array}{l}\text {-- Rights to } \\
\text { Harvest }\end{array}$ & $\begin{array}{l}\text { Granted to local } \\
\text { groups, some } \\
\text { limits }\end{array}$ & $\begin{array}{l}\text { Granted to local } \\
\text { groups, some limits }\end{array}$ & $\begin{array}{l}\text { Granted to local } \\
\text { groups }\end{array}$ & $\begin{array}{l}\text { Granted to local } \\
\text { groups, very limited }\end{array}$ \\
\hline $\begin{array}{l}\text {-- Rights to } \\
\text { Manage }\end{array}$ & $\begin{array}{l}\text { Granted to local } \\
\text { groups, some } \\
\text { limits }\end{array}$ & $\begin{array}{l}\text { Granted to local } \\
\text { groups, some limits }\end{array}$ & $\begin{array}{l}\text { Granted to local } \\
\text { groups, some limits }\end{array}$ & $\begin{array}{l}\text { Not available to local } \\
\text { groups }\end{array}$ \\
\hline $\begin{array}{l}\text { - Rights to } \\
\text { Exclude }\end{array}$ & $\begin{array}{l}\text { Granted to local } \\
\text { groups }\end{array}$ & $\begin{array}{l}\text { Granted to local } \\
\text { groups, some limits }\end{array}$ & $\begin{array}{l}\text { Granted to local } \\
\text { groups, some limits }\end{array}$ & $\begin{array}{l}\text { Not available to local } \\
\text { groups }\end{array}$ \\
\hline $\begin{array}{l}\text {-- Rights to } \\
\text { Transfer }\end{array}$ & $\begin{array}{l}\text { Not available to } \\
\text { local groups }\end{array}$ & $\begin{array}{l}\text { Limited rights granted } \\
\text { to local groups }\end{array}$ & $\begin{array}{l}\text { Limited rights } \\
\text { granted to local } \\
\text { groups }\end{array}$ & $\begin{array}{l}\text { Not available to local } \\
\text { groups }\end{array}$ \\
\hline \multicolumn{5}{|l|}{ 4. Outcomes } \\
\hline $\begin{array}{l}\text { Participation/ } \\
\text { Decentralization }\end{array}$ & $\begin{array}{l}\text { High levels of } \\
\text { participation and } \\
\text { decentralization }\end{array}$ & $\begin{array}{l}\text { Significant levels of } \\
\text { participation and } \\
\text { decentralization }\end{array}$ & $\begin{array}{l}\text { High levels of } \\
\text { participation and } \\
\text { decentralization }\end{array}$ & $\begin{array}{l}\text { Limited participation } \\
\text { and decentralization }\end{array}$ \\
\hline $\begin{array}{l}\text { Resource use } \\
\text { patterns }\end{array}$ & $\begin{array}{l}\text { Decentralization } \\
\text { limits resource } \\
\text { use and improves } \\
\text { resources } \\
\text { condition }\end{array}$ & $\begin{array}{l}\text { Decentralization limits } \\
\text { resource use and } \\
\text { improves resource } \\
\text { condition }\end{array}$ & $\begin{array}{l}\text { Decentralization } \\
\text { limits resource use } \\
\text { and improves } \\
\text { resource condition }\end{array}$ & $\begin{array}{l}\text { Institutionalization is } \\
\text { limited and local use } \\
\text { patterns remain the } \\
\text { same }\end{array}$ \\
\hline
\end{tabular}




\section{$\underline{\text { References }}$}

Adasiak, Allen. 1979. "Alaska's Experience with Limited Entry." Journal of the Fisheries Research Board of Canada 36(7):770-82.

Agarwal, Anil. 1997. Dark Truths and Lost Woods. Down to Earth 6(2): 32-40.

Agrawal, Arun. 1994. "Rules, Rule Making, and Rule Breaking: Examining the Fit Between Rule Systems and Resource Use." In Rules, Games, and Common-Pool Resources, ed. Elinor Ostrom, Roy Gardner, and James M. Walker, 267-82. Ann Arbor: University of Michigan Press.

Agrawal, Arun. 1999. Decentralization in Nepal: A Comparative Analysis. Oakland: ICS Press.

Agrawal, Arun, and Gautam Yadama. 1997. "How do Local Institutions Mediate Market and Population Pressures on Resources? Forest Panchayats in Kumaon, India." Development and Change 28: 435-65.

Agrawal, Arun, and Jesse C. Ribot. 1999. Accountability in Decentralization: A Framework with South Asian and West African Case. Journal of Developing Areas 33(summer): 473-502.

Agrawal, Arun, S. Shah, M. Karmacharya, and B. Kama. 1999. Conservation with Communities: The Parks and People Program in Nepal. IFRI Report, Bloomington, Indiana: Workshop in Political Theory and Policy Analysis, Indiana University.

Arnold, J. E. M., and J. Gabriel Campbell. 1986. "Collective Management of Hill Forests in Nepal: The Community Forestry Development Project." In Proceedings of the Conference on Common Property Resource Management, National Research Council, 425-54. Washington, DC: National Academy Press.

Arora, Dolly. 1994. From State Regulation to People's Participation: Case of Forest Management in India. Economic and Political Weekly 29(March 19): 691-98.

Basnet, K. 1992. "Conservation Practice in Nepal: Past and Present." Ambio 21:390-93.

Berkes, Fikret, ed. 1989. Common Property Resources; Ecology and Community-Based Sustainable Development. London: Belhaven.

Blomquist, William. 1992. Dividing the Waters: Governing Groundwater in Southern California. San Francisco: ICS Press.

Booth, Philip. 1995. "Decentralization and Land-use Planning in France: A Fifteen Year Review." Policy and Politics 26(1): 89-105. 
Bromley, Daniel W., David Feeny, Margaret McKean, Pauline Peters, Jere Gilles, Ronald Oakerson, C. Ford Runge, and James Thomson, eds. 1992. Making the Commons Work: Theory, Practice, and Policy. San Francisco, CA: ICS Press.

Bruce, John. 1995. Legal Bases for the Management of Land-Based Natural Resources as Common Property. Rome, Italy: Food and Agriculture Organization of the United Nations; Forests, Trees and People Program.

Bruce, John W., Louise Fortmann, and Calvin Nhira. 1993. "Tenures in Transition, Tenures in Conflict: Examples from the Zimbabwe Social Forest." Rural Sociology 58(4):626-42.

Bruce, John W., and Shem E. Migot-Adholla, eds. 1994. Searching for Land Tenure Security in Africa. Dubuque, IA: Kendall/Hunt.

Clark, John. 1995. "The State, Popular Participation, and the Voluntary Sector." World Development 23(4): 593-601.

Commons, John R. 1968. Legal Foundations of Capitalism. Madison: University of Wisconsin Press.

Dahal, Dev Raj, 1996. The Challenge of Good Governance: Decentralization and Development in Nepal. Kathmandu, Nepal: Center for Governance and Development Studies.

Dahl, Robert A., and Charles E. Lindblom. 1963. Politics, Economics and Welfare: Planning and Politico-Economic Systems Resolved into Basic Social Processes. New York: Harper.

Demsetz, Harold. 1967. "Toward a Theory of Property Rights." American Economic Review 57 (May): 347-59.

Dillinger, W. 1994. Decentralization and its Implications for Urban Service Delivery. Urban Management Program Discussion Paper 16. Washington DC: The World Bank.

Eckholm, Erik. 1976. Losing Ground: Environmental Stress and World Food Prospects. New York: Norton.

Evans, Peter. 1992. "A Virtuous Cycle Model of Rural-urban Development: Evidence from a Kenyan Small Town and its Hinterland." Journal of Development Studies 28(4): 640-67.

Feder, Gershon, and David Feeny. 1991. "Land Tenure and Property Rights: Theory and Implications for Development Policy." World Bank Economic Review 5(1):135-53.

Feder, Gershon, T. Onchan, Y. Chalamwong, and C. Hangladoran. 1988. Land Policies and Form Productivity in Thailand. Baltimore, MD: Johns Hopkins University Press. 
Food and Agriculture Organization 1999. Status and Progress in the Implementatidn of National Forest Programmes: Outcomes of an FAO Worldwide Survey", Mimeo, Rome: FAO.

Frey, Bruno S., and Reiner Eichenberger. 1999. "A New Proposal for Federalism and Democracy in Developing Countries." In Institutions and Collective Choice in Develophent Countries. Applications of the Theory of Public Choice, ed. Mwangi S. Kimenyi and John Mukum Mbaku, 315-26. Singapore: Ashgate.

Gadgil, Madhav and Ramachnadra Guha. 1995. Ecology and Equity: Use and Abuse of Nature in Contemporary India. New Delhi: Penguin.

Goodwin, M., S. Duncan, and S. Halford. 1996. "Regulation Theory, the Local State and the Transition of Urban Politics." Environment and Planning D: Society and Space. 11(1): 6788.

Heinen, J. T., and B. Kattel. 1992. "A Review of Conservation Legislation in Nepal: Past Progress and Future Needs." Environmental Management 16:723-33.

HMG/UNDP. 1994. Parks and People Project. Report \# NEP/94/001 /A/01/99. Kathmandu: UNDP.

IADB (Inter-American Development Bank). 1991. Economic and Social Progress in Latin America. Washington DC: IADB.

Iswharan, N. and W. Erdelen. 1990. "Conserving Sunharaja: An Experiment in Sustainable Development in Sri Lanka." Ambio 12:237-44.

Ives, Jack D. and Bruno Messerli. 1989. The Himalayan Dilemma: Reconciling Development and Conservation. London: Routledge.

Jeffery, Roger and Nandini Sundar (eds) 1999. A New Moral Economy for India's Forests? Discourses of Community and Participation. Sage: New Delhi

KFGC. 1921. Report of the Forest Grievances Committee for Kumaon. Government of Uttar Pradesh.

Khare, Arvind, Madhu Sarin, N.C. Saxena, Subhabrata Palit, Seema Bathla, Farhad Vania, M. Satyanarayana. 2000. Joint Forest Management: Policy, Practice and Prospects. London: International Institute for Environment and Development.

Kiser, Larry L., and Elinor Ostrom. 1982. "The Three Worlds of Action: A Metatheoretical Synthesis of Institutional Approaches." In Strategies of Political Inquiry, ed. Elinor Ostrom, 179-222. Beverly Hills, CA: Sage. 
Kolavalli, Shashi. 1995. Joint Forest Management: Superior Property Rights? Economic and Political Weekly 30 (July 29): 1933-38.

Krishnaswamy, Ajit. 1995. Sustainable Development and Community Forest Management in Bihar, India. Society and Natural Resources 8: 339-50.

- Kumar, Neeraj. 2000. All is not Green With JFM in India. Forests, Trees, and People Newsletter 42: 46-50.

Lam, Wai Fung. 1998. Governing Irrigation Systems in Nepal: Institutions, Infrastructure, and Collective Action. Oakland, CA: ICS Press.

Larson, Bruce A., and Daniel W. Bromley. 1990. "Property Rights, Externalities, and Resource Degradation: Locating the Tragedy." Journal of Development Economics 33(2) (Oct.): 23562.

Maass, Arthur, and Raymond L. Anderson. 1986.. . . and the Desert Shall Rejoice: Conflict, Growth, and Justice in Arid Environments. Malabar, FL: R. E. Krieger.

Mahapatra, Richard. 2000. Community Forest Management: The Nepalese Experience. Down to Earth 8(19): 1-10.

Maniates, Michael. 1990. "Organizational Designs for Achieving Sustainability: The Opportunities, Limitations, and Dangers of State-local Collaboration for Common Property Management." Paper presented at the First Annual Meeting of the International Association for the Study of Common Property, Durham, NC, Sept. 27-30, 1990.

Martin, Edward G. 1986. "Resource Mobilization, Water Allocation, and Farmer Organization in Hill Irrigation Systems in Nepal." Ph.D. diss., Cornell University.

Martin, Edward G., and Robert Yoder. 1983a. "Review of Farmer-Managed Irrigation in Nepal." In Water Management in Nepal: Proceedings of the Seminar on Water Management Issues, July 31-August 2, 82-91. Kathmandu, Nepal: Ministry of Agriculture, Agricultural Projects Services Centre, and the Agricultural Development Council.

Martin, Kent O. 1979. "Play by the Rules or Don't Play at All: Space Division and Resource Allocation in a Rural Newfoundland Fishing Community." In North Atlantic Maritime Cultures: Anthropological Essays on Changing Adaptations, ed. Raoul Anderson, 276-98. The Hague, Netherlands: Mouton.

Mawhood, P. (ed) 1983. Local Government in the Third World: The Experience of Tropical Africa. Chichester: Wiley. 
McCay, Bonnie J., and James M. Acheson, eds. 1987. The Question of the Commons: The Culture and Ecology of Communal Resources. Tucson: University of Arizona Press.

Migot-Adholla, Shem E., Peter Hazell, Benoit Blarel, and Frank Place. 1991. "Indigenous Land Rights Systems in Sub-Saharan Africa: A Constraint on Productivity?" World Bank Economic Review 5(1): 155-75.

Miller, David. 1989. "The Evolution of Mexico's Spiny Lobster Fishery." In Common Property Resources: Ecology and Community-Based Sustainable Development, ed. Fikret Berkes, 185-98. London: Belhaven Press.

Montias, John Michael. 1976. The Structure of Economic Systems. New Haven, CT: Yale University Press.

Nepal, S. K., and K. Weber. 1994. "A Buffer Zone for Biodiversity Conservation: Viability of the Concept in Nepal's Royal Chitwan National Park." Environmental Conservation 21:333-41.

Oakerson, Ronald J. 1992. "Analyzing the Commons: A Framework." In Making the Commons Work: Theory, Practice, and Policy, ed. Daniel W. Bromley et al., 41-59. San Francisco, CA: ICS Press.

Ostrom, Elinor. Forthcoming. "Institutional Rational Choice: An Assessment of the IAD Framework." In Theories of the Policy Process, ed. Paul Sabatier. Boulder, CO: Westview Press.

Ostrom, Elinor. 1990. Governing the Commons: The Evolution of Institutions for Collective Action. New York: Cambridge University Press.

Ostrom, Elinor. 1999. Self-Governance and Forest Resources. Occasional Paper \#20, Bogor: CIFOR.

Ostrom, Elinor, Roy Gardner, and James Walker. 1994. Rules, Games, and Common-Pool Resources. Ann Arbor: University of Michigan Press.

Ostrom, Elinor, and Edella Schlager. 1996. "The Formation of Property Rights." In Rights to Nature, ed. Susan Hanna, Carl Folke, and Karl-Göran Mäler, 127-56. Washington, DC: Island Press.

Ostrom, Elinor, Larry Schroeder, and Susan Wynne. 1993. Institutional Incentives and Sustainable Development: Infrastructure Policies in Perspective. Boulder, CO: Westview Press.

Ostrom, Vincent. 1988. "Cryptoimperialism, Predatory States, and Self-Governance." In Rethinking Institutional Analysis and Development: Issues, Alternatives, and Choices, ed. Vincent Ostrom, David Feeny, and Hartmut Picht, 43-68. San Francisco, CA: ICS Press. 
Place, Frank, and Peter Hazell. 1993. "Productivity Effects of Indigenous Land Tenure Systems in Sub-Saharan Africa." American Journal of Agricultural Economics 75:10-19.

Poffenberger, Mark, and Chhatrapati Singh. 1996. Communities and the State: Reestablishing the Balance in Indian Forest Policy. In Mark Poffenberger and Betsy McGean (eds) Village Voices, Forest Choices. Pp. 56-85. Delhi: Oxford University Press.

Poffenberger, Mark, and Betsy McGean (eds) 1996. Village Voices, Forest Choices. Delhi: Oxford University Press.

Rakodi, C. 1986. "State and Class in Africa: A Case for Extending Analyses of the Form and Functions of the National State to the Urban Local State." Environment and Planning D: Society and Space 4: 419-46.

Raychaudhuri, Bikash. 1980. The Moon and the Net: Study of a Transient Community of Fishermen at Jambudwip. Calcutta: Government of India Press, Anthropological Survey of India.

Rhodes, R.A.W. 1988. Beyond Westminster and Whitehall: The Sub-Central Governments of Britain. London: Unwin Hyman.

Ribot, Jesse. C. 1999. Decentralization, participation, and accountability in Sahelian forestry: Legal instruments of political-administrative control. Africa 69(1): 23-65.

Rondinelli, Dennis and John Nellis. 1986. "Assessing Decentralization Policies in Developing Countries: The Case for Cautious Optimism." Development Policy Review 4(1): 3-23.

Rondinelli, Dennis, James S. McCullough, and Ronald W. Johnson. 1989. "Analyzing Decentralization Policies in Developing Countries: A Political Economy Approach." Development and Change 20(1): 57-87.

Saberwal, V. 1997. "Bureaucratic Agendas and Conservation Policy in Himachal Pradesh." Indian Economic and Social History Review 34:465-98.

Schlager, Edella. 1994. "Fishers' Institutional Responses to Common-Pool Resource Dilemmas." In Rules, Games, and Common-Pool Resources, ed. Elinor Ostrom, Roy Gardner, and James M. Walker, 247-65. Ann Arbor: University of Michigan Press.

Schlager, Edella, and Elinor Ostrom. 1992. "Property-Rights Regimes and Natural Resources: A Conceptual Analysis." Land Economics 68(3) (Aug.): 249-62.

Schlager, Edella, and Elinor Ostrom. 1993. "Property-Rights Regimes and Coastal Fisheries: An Empirical Analysis." In The Political Economy of Customs and Culture: Informal Solutions 
to the Commons Problem, ed. Terry L. Anderson and Randy T. Simmons, 13-41. Lanham, MD: Rowman \& Littlefield.

Sivaramakrishnan, K. 1996. Forests, Politics, and Governance in Bengal: 1794-1994, Vols. 1\&2. PhD Thesis, Yale University.

Sivaramakrishnan, K. and Arun Agrawal. 1998. "Regional Modernities in Stories and Practices of Development." YCIAS Working Paper \#1, New Haven: Yale University.

Siy, Robert Y., Jr. 1982. Community Resource Management: Lessons from the Zanjera. Quezon City, Philippines: University of the Philippines Press.

Skaria, Ajay. 1999. Hybrid Histories. Delhi: Oxford University Press.

Somanathan, E. 1991. "Deforestation, Property Rights, and Incentives in Central Himalaya." Economic and Political Weekly 26:PE37-46.

'Sundar, Nandini. 2000. Unpacking the "Joint" in Joint Forest Management. Development and Change 31: 255-79.

Sundar, Nandini. 1997. Subalterns and Sovereigns: An Anthropological History of Bastar, 18541996. New Delhi: Oxford University Press.

Tang, Shui Yan. 1992. Institutions and Collective Action: Self-Governance in Irrigation. San Francisco, CA: ICS Press.

Tang, Shui Yan. 1994. "Building Community Organizations: Credible Commitment and the New Institutional Economics." Human Systems Management 13:221 -32.

Varughese, George. 1999. "Villagers, Bureaucrats, and Forests in Nepal: Designing Governance for a Complex Resource." Ph.D. diss., Indiana University, Bloomington.

Veltmeyer, Henry. 1997. "Latin America in the New World Order." Canadian Journal of Sociology 22(2): 207-29.

The World Bank. 1991. Urban Policy and Economic Development: An Agenda for the 1990s. Washington DC: The World Bank.

Wunsch, J. S. and Dele Olowu. 1990. The Failures of the Centralized State: Institutions and SelfGovernance in Africa. Boulder, CO: Westview Press. 